\title{
Епідеміологічна оцінка носового носійства Staphylococcus aureus у пацієнтів, яким планується імплантація зубів
}

\author{
Я.В. Шкорботун ${ }^{1,2}$, А.Г. Салманов ${ }^{1}$ \\ 'Національний університет охорони здоров'я України імені П.Л. Шупика, Київ, Україна \\ Державна наукова установа «Науково-практичний центр профілактичної та клінічної \\ медицини» Державного управління справами, Київ, Україна
}

\begin{abstract}
Анотація. Мета: епідеміологічна оцінка носійства Staphylococcus aureus (S. aureus) у пацієнтів із хронічним синуситом, яким планується дентальна імплантація. Об'єкт і методи дослідження. Обстежено 218 осіб віком 21-60 років (98 чоловіків, 120 жінок), що мали різні форми хронічного синуситу (163 - з поліпозом, 55 - без поліпозу) та яким планувалася дентальна імплантація. Виділення культур мікроорганізмів та їх ідентифікацію здійснювали за допомогою рутинних методів, які базуються на чинних нормативних документах. Чутливість до антибіотиків визначали диско-дифузійним методом. Результати. Встановлено, що середній носовий хід пацієнтів із хронічним риносинуситом, яким планувалася дентальна імплантація, колонізований різними мікроорганізмами. Найчастіше виділено S. aureus (39,7\%), S. epidermidis (17\%) та Streptococcus spp. (10,3\%). Відмінностей у рівні виявлення бактерій за критеріями наявності атопії, бронхіальної астми або поточного статусу курця не встановлено. У пацієнтів із хронічним риносинуситом без поліпів у носі відмічено значно вищий рівень виявлення різних бактерій, ніж у пацієнтів з поліпами. Частота ізоляції окремих бактерій між хворими на хронічний риносинусит без поліпів та з поліпами у носі відрізнялася. S. aureus та S. epidermidis виявлені частіше у хворих на хронічний риносинусит з поліпами, тоді як Enterococcus faecalis та Streptococcus spp. — у пацієнтів без поліпів у носі. Найбільшу чутливість штами S. aureus виявили до гентаміцину, ципрофлоксацину, офлоксацину, левофлоксацину, цефазоліну та цефуроксиму, найменшу - до ампіциліну, кларитроміцину та еритроміцину. Метицилінрезистентні штами S. aureus становили 21\% від загальної кількості виділених стафілококів. Висновок. Хронічний риносинусит і носійство S. aureus, зокрема метицилінрезистентних штамів, в порожнині носа - поширена проблема, з якою часто стикаються пацієнти, яким показана дентальна імплантація. При розробці заходів профілактики та ефективного лікування бактеріальних ускладнень дентальної імплантації необхідно враховувати дані щодо мікробних патогенів, які виділяють у пацієнтів при хронічному риносинуситі, і їх можливу резистентність до антибіотиків.

Ключові слова: хронічний риносинусит, дентальна імплантація, S. aureus, антибіотики, антибіотикорезистентність.
\end{abstract}

\section{Вступ}

Хронічний риносинусит (ХРС) - одне 3 найпоширеніших хронічних захворювань, яке пов'язане з високим соціальноекономічним тягарем від прямих і непрямих витрат. ХРС часто відмічають у пацієнтів із супутніми захворюваннями, такими як бронхіальна астма (БА), респіраторна алергія та хронічне обструктивне захворювання легень [1].

За даними літератури, в Україні $>70 \%$ загальної чисельності населення потребують стоматологічного ортопедичного лікування, а саме заміщення вад зубних рядів чи повторного протезування [2]. Серед цих осіб суттєвою є частка хворих на ХРС.

Пріоритетним і перспективним напрямком сучасної стоматології $\epsilon$ широке використання імплантації для лікування різноманітних дефектів щелепно-лицьової ділянки, зокрема у разі відновлення цілісності зубних рядів пацієнтів [3]. Проте незважаючи на успіхи дентальної імплантології, все ще відзначається досить велика частка післяопераційних ускладнень, у тому числі інфекційних. Основна причина ускладнень - виникнення інфекційно-запальних процесів у ділянці операції, кількість яких значно варіює і становить 5-30\% [4]. Тому розгляд причин їх виникнення та розробка методів попередження мають важливе практичне значення.

Дентальна імплантація - ефективний метод відновлення функції жування, однак $\epsilon$ фактори, які можуть негативно впливати на її успішність і зумовлювати ризик використання імплантатів. Ключовий чинник, який впливає на успішність імплантації, - назальне носійство Staphylococcus aureus (S. aureus) у пацієнтів, що може викликати гнійно-запальну інфекцію в ділянці встановлення імплантатів у ротовій порожнині. За даними досліджень, носійство S. aureus часто відмічають у пацієнтів із ХРС, що може створювати труднощі для успішної дентальної імплантації. Періодична колонізація S. aureus порожнини носа у здорових людей сягає 50\% [5-7].

Мікробіологічні дослідження в отоларингології залишаються актуальними протягом багатьох років [8]. Це пов'язано насамперед $з$ тим, що верхні дихальні шляхи $\epsilon$ ділянкою взаємодії мікрофлори зовнішнього середовища та організму людини. Звичайно, така локалізація зумовлює нестерильність слизових оболонок та формування нормальної мікробіоти цього органу, що формує колоніальну резистентність [9].

У ході лікування ХРС обгрунтоване застосування антимікробної терапії при розвитку загострень з ознаками бактеріальної складової в патогенезі має базуватися в ідеалі на культуральних дослідженнях. При цьому розуміння складу мікрофлори та моделей резистентності до антибіотиків (АБ) $\epsilon$ необхідним при виборі лікування пацієнтів із ХРС [10].У дослідженнях мікробіома при ХРС повідомляли про різні мікроорганізми, і відмічено їх важливе значення у патофізіології хронічного запалення. При виборі АБ рекомендується керуватися результатами бактеріального посіву [10-13].

Надмірне або необгрунтоване застосування АБ широкого спектру дії може викликати резистентність штамів мікроорганізмів до цих препаратів. Отже, з'ясування останніх тенденцій в культурах мікроорганізмів, виділених від пацієнтів із ХРС, $\epsilon$ важливим для управління інфекціями і запобігання стійкості до АБ, зокрема при дентальній імплантації.

Однак незважаючи на актуальність проблеми інфекційних ускладнень при дентальній імплантації роль назального носійства S. aureus у пацієнтів із ХРС вивчена недостатньо. У той самий час як в Україні, так і в інших країнах, відмічають випадки зловживання АБ при лікуванні ХРС (наприклад їх призначають за відсутності даних про культуру), що викликає ризик появи атипових бактеріальних штамів і штамів, стійких до АБ.

У доступній літературі зазначеній проблемі присвячені поодинокі дослідження, які висвітлюють питання лише з боку лікування ХРС без урахування ризиків для дентальної імплантації. Тому дослідження щодо ризиків при дентальній імплантації паці$\epsilon$ там із ХРC, які $\epsilon$ носіями S. aureus, $є$ актуальними.

Мета дослідження - епідеміологічна оцінка носійства S. aureus у пацієнтів із хронічним синуситом, яким планується дентальна імплантація. 


\section{Об'єкт і методи дослідження}

\section{Дизайн дослідження}

Дослідження грунтується на даних спостереження пацієнтів в період 2015-2020 рр. У дослідження включено 218 пацієнтів (98 чоловіків, 120 жінок) віком 21-60 років, що мали різні форми хронічного синуситу ( 163 - з поліпозом, 55 - без поліпозу), яким планувалася дентальна імплантація.

Усім пацієнтам встановлено діагноз «хронічний синусит» відповідно до діагностичних критеріїв EPOS (European Position Paper on Rhinosinusitis and Nasal Polyps) [11]. Аналізували демографічні дані (вік, стать), статус тютюнопаління, статус атопії, наявність БА в анамнезі. Враховували динаміку показників виявлення бактерій за роками. Для цього досліджуваний період розділено на три періоди: 2015-2016, 2017-2018 та 2019-2020рр. Усі пацієнти проживали у Києві та Київській обл. і протягом останнього року не застосовували антибактеріальну терапію.

Критерії виключення з дослідження: наявність грибкового тіла синусу, алергічний грибковий синусит, одонтогенний синусит, муковісцидоз, антибіотикотерапія протягом останніх 12 міс.

\section{3бір та дослідження зразків}

У всіх пацієнтів брали мазок із середнього носового ходу (CHX) за допомогою стерильного тампону з дотриманням вимог асептики. Матеріал доставляли у бактеріологічну лабораторію протягом 30 хв.

Виділення культур мікроорганізмів та їх ідентифікацію здійснювали за допомогою рутинних методів, які базуються на чинних нормативних документах. Чутливість до АБ визначали диско-дифузійним методом, результати оцінювали відповідно до наказу Міністерства охорони здоров'я України від 05.04.2007 р. № 167.

\section{Статистичний аналіз}

Статистичну обробку результатів дослідження проводили за допомогою методів варіаційної статистики з використанням програми «StatSoft», «Statistica» v. 12.0. Відносні величини (відображали частоту ознаки у виборці) - у вигляді відсотків (\%). Для показників групових порівнянь використовували статистику тесту $X^{2}$ та t-тест Стьюдента. Статистичну значимість приймали для $\mathrm{p}<0,05$.

\section{Результати}

у ході дослідження (2015-2020рр.) бактерії виділені у 174 із 218 пацієнтів (79,8\%). За показниками статі та віку відмінностей у групах із виділеною бактеріальною культурою не виявлено ( $p=0,731$ та $p=0,712$ відповідно).

У пацієнтів з ХРС без поліпів у носі відмічено значно вищий рівень виявлення бактерій, ніж пацієнтів з поліпами (81,7 та $74,5 \%$ відповідно, $\mathrm{p}=0,032)$. Відмінностей у рівні виявлення бактерій за критеріями наявності атопії, БА або поточного статусу курця не встановлено ( $p>0,05$ для кожного показника) (табл. 1).

Таблиця 1 Порівняння частоти ізоляції бактерій за формою XРС

\begin{tabular}{lccccccccc}
\hline \multirow{2}{*}{ Показник } & \multicolumn{2}{c}{ Назальний поліп } & \multicolumn{2}{c}{ Атопія } & \multicolumn{2}{c}{ БА } & \multicolumn{2}{c}{ Курець } \\
\cline { 2 - 10 } & Так & $\mathbf{H i}$ & Так & Hi & Так & Hi & Так & Hi \\
\hline Кількість пацієнтів & 163 & 55 & 29 & 189 & 14 & 204 & 32 & 186 \\
\hline Частота ізоляції, \% & 74,5 & 81,7 & 65,1 & 74,9 & 71,9 & 77,3 & 76,3 & 77,1 \\
\hline p & \multicolumn{2}{c}{0,032} & 0,081 & 0,611 & 0,831 \\
\hline
\end{tabular}

Загалом у 174 пацієнтів із позитивними культурами виділено 348 штамів, $78(44,8 \%)$ пацієнтів мали один ізольований мікроорганізм, тоді як 96 (55,2\%) - множинні. Найчастіше виділяли грампозитивні бактерії (77,6\%), зокрема S. aureus (39,7\%), S. epidermidis (17\%), за ними слідують Streptococcus spp. (10,3\%), Enterococcus fecalis та Corynebacterium (2,9\%).

Грамнегативні бактерії становили 22,4\%. Серед них найбільшу частку мали Escherichia coli (E. coli) (4,9\%), Klebsiella pneumoniae (4\%), Enterobacter spp. (3,4\%), Klebsiella oxytoca $(3,2 \%)$ та Proteus mirabilis (2,6\%). Частка інших грамнегативних бактерій не перевищувала 1,5\% (Citrobacter spp., Haemophilus spp.). Результати мікробіологічного дослідження пацієнтів із ХРС представлені у табл. 2.
Таблиця 2 Кількість та відсоток бактеріальних ізолятів, виділених у пацієнтів із ХРС (348 штамів)

\begin{tabular}{|c|c|c|c|}
\hline \multirow{2}{*}{ Мікроорганізми } & \multirow{2}{*}{$\begin{array}{c}\text { Кількість } \\
\text { ізолятів } \\
(\mathrm{n}=348)\end{array}$} & \multicolumn{2}{|c|}{$\begin{array}{l}\text { XPC, } \\
\text { n (\%) }\end{array}$} \\
\hline & & $\begin{array}{c}\text { Без поліпів } \\
(n=108)\end{array}$ & $\begin{array}{c}3 \text { поліпами } \\
(\mathrm{n}=240)\end{array}$ \\
\hline Грампозитивні аеробні бактерії & $270(77,6)$ & $85(78,7)$ & $185(77,1)$ \\
\hline S. aureus & $138(39,7)$ & $41(38 \%)$ & $97(40,4)$ \\
\hline S. epidermidis & $59(17 \%)$ & $17(15,7)$ & $42(17,5)$ \\
\hline Enterococcus fecalis & $27(7,8)$ & $13(12,0)$ & $14(5,8)$ \\
\hline Streptococcus spp. & $36(10,3)$ & $13(12,0)$ & $23(9,6)$ \\
\hline Corynebacterium & $10(2,9)$ & $1(0,9)$ & $9(3,8)$ \\
\hline Грамнегативні аеробні бактерії & $79(22,4)$ & $23(21,3)$ & $55(22,9)$ \\
\hline E. coli & $17(4,9)$ & $6(5,6)$ & $11(4,6)$ \\
\hline Enterobacter spp. & $12(3,4)$ & $4(3,7)$ & $8(4,6)$ \\
\hline Klebsiella pneumoniae & $14(4 \%)$ & $2(1,9)$ & $12(5,0)$ \\
\hline Klebsiella oxytoca & $11(3,2)$ & $4(3,7)$ & $7(2,9)$ \\
\hline Proteus mirabilis & $9(2,6)$ & $4(3,7)$ & $5(2,1)$ \\
\hline Citrobacter spp. & $5(1,4)$ & $2(1,9)$ & $3(1,3)$ \\
\hline Haemophilus spp. & $5(1,4)$ & - & $5(2,1)$ \\
\hline Інші & $5(1,4)$ & $1(0,9)$ & $4(1,7)$ \\
\hline
\end{tabular}

Частота ізоляції конкретних бактерій у хворих на ХРС без поліпів та з поліпами носа дещо відрізнялася. Серед грампозитивних штамів S. aureus та S. epidermidis відмічали частіше у хворих на ХРС з поліпами, тоді як Enterococcus faecalis та Streptococcus spp. - у хворих без поліпів у носі. Грамнегативні бактерії також мали відмінності. Так, Klebsiella pneumoniae та Enterobacter spp. виявлено частіше у хворих з поліпами, a E. coli та Klebsiella oxytoca - без поліпів (див. табл. 2).

Далі проаналізовані тенденції щодо частоти виявлення вищезазначених бактерій у період з січня 2015 по грудень 2020 р. Що стосується кількості бактерій, виділених у кожний період, то з січня 2015 по грудень 2016 р. виявлено 97, з січня 2017 по грудень 2018 р. - 111, з січня 2019 по грудень 2020 р. 140 штамів. S. aureus, S. epidermidis, Streptococcus spp. та Klebsiella pneumoniae продемонстрували суттєві тенденції до зростання ( $p=0,007, p=0,0029, p=0,004$ та $p=0,002$ відповідно), тоді як Corynebacterium, E. coli та Enterobacter spp. - суттєві тенденції до зменшення ( $p<0,001, p<0,008$ та $p=0,003$ відповідно). Представлені у табл. 3 дані свідчать, що найбільш поширеним збудником, виділеним із $\mathrm{CHX}$ пацієнтів із XPC, $\in$ S. aureus.

Таблиця 3 Тенденції часто культивованих бактерій з часом

2015-2016pp. 2017-2018 pp. 2019-2020pp.

$\begin{array}{lllll}\text { Miкроорганізм } & \text { (97 штамів, \%) } & (111 \text { штамів, \%) } & (140 \text { штамів, \%) } & \text { p }\end{array}$

\begin{tabular}{lcccc}
\hline S. aureus & 35,1 & 40,5 & 42,1 & 0,007 \\
\hline S. epidermidis & 15,5 & 16,2 & 18,6 & 0,0029 \\
\hline Enterococcus fecalis & 8,2 & 10,8 & 5,0 & 0,003 \\
\hline Streptococcus spp. & 9,3 & 9,9 & 11,4 & 0,004 \\
\hline Corynebacterium & 7,2 & 0,9 & 1,4 & 0,001 \\
\hline E. coli & 7,2 & 3,6 & 4,3 & 0,008 \\
\hline Enterobacter spp. & 5,2 & 3,6 & 2,1 & 0,003 \\
\hline Klebsiella pneumoniae & 4,1 & 0,9 & 6,4 & 0,002 \\
\hline Klebsiella oxytoca & 3,1 & 3,6 & 2,9 & 0,007 \\
\hline Proteus mirabilis & 2,1 & 3,6 & 2,1 & 0,072 \\
\hline Citrobacter spp. & 1,0 & 3,6 & - & $<0,001$ \\
\hline Haemophilus spp. & 1,0 & 0,9 & 2,1 & 0,068 \\
\hline IHwi & 1,0 & 1,8 & 1,4 & 0,082 \\
\hline
\end{tabular}

Враховуючи клінічну та епідеміологічну значимість та тенденції до зростання, визначено чутливість S. aureus до АБ. Чутливість S. aureus визначена до тих АБ (загалом 16), які застосовують в Україні для лікування та профілактики. Встановлено суттєві відмінності щодо рівня резистентності досліджених штамів S. aureus до тестованих АБ (табл. 4). 
Таблиця 4 Чутливість до АБ S. aureus, виділених із СНХ пацієнтів із ХPC Чутливий,
АБ $\begin{gathered}\text { Помірно стійкий, } \\ \text { абсолійкий, } \\ \text { абсолютне число }\end{gathered}$ абсолютне число (\%) абсолютне число (\%)

\begin{tabular}{lccc}
\hline Ампіцилін & $14(10,1)$ & - & $124(89,9)$ \\
\hline Оксацилін & $109(79,0)$ & - & $29(21,0)$ \\
\hline Цефалексин & - & - & $6(4,3)$ \\
\hline Цефазолін & $126(91,3)$ & $6(4,3)$ & $6(4,3)$ \\
\hline Цефуроксим & $126(91,3)$ & $6(4,3)$ & $6(4,3)$ \\
\hline Левоміцетин & $115(83,3)$ & $11(8,0)$ & $12(8,7)$ \\
\hline Тетрациклін & $105(76,1)$ & - & $33(23,9)$ \\
\hline Еритроміцин & $46(33,3)$ & $23(16,7)$ & $69(50,0)$ \\
\hline Рифампіцин & $126(91,3)$ & - & $12(8,7)$ \\
\hline Кларитроміцин & $34(24,6)$ & $25(18,1)$ & $79(57,2)$ \\
\hline Гентаміцин & $138(100)$ & - & - \\
\hline Ципрофлоксацин & $132(95,7)$ & - & $6(4,3)$ \\
\hline Офлоксацин & $132(95,7)$ & - & $6(4,3)$ \\
\hline Левофлоксацин & $132(95,7)$ & - & $6(4,3)$ \\
\hline Кліндаміцин & $60(43,5)$ & $13(9,4)$ & $65(47,1)$ \\
\hline Азитроміцин & $115(83,3)$ & $17(12,3)$ & $6(4,3)$
\end{tabular}

За результатами аналізу даних щодо чутливості до тестованих АБ встановлено, що найбільшу чутливість S. aureus має до гентаміцину (100\% зразків), фторхінолонів (ципрофлоксацин, офлоксацин, левофлоксацин - 95,7\%), цефазоліну, цефуроксиму, рифампіцину (91,3\%). Найменша чутливість відмічається до ампіциліну (10,1\%), кларитроміцину (24,6\%), еритроміцину (33,3\%). Питома вага резистентних до метициліну штамів S. aureus (methicillin-resistant S. aureus - MRSA) становила 21\%.

\section{Обговорення}

У представленому дослідженні проаналізовано 348 бактеріальних ізолятів, виділених із 174 зразків культур. Виявлено, що в період 2015-2020 рр. серед мікроорганізмів, виділених у пацієнтів із ХРС, грампозитивні аеробні бактерії були основними ізолятами, в першу чергу S. aureus (39,7\%), S. epidermidis (17\%), Streptococcus spp. (10,3\%) та Enterococcus fecalis $(7,7 \%)$. Грамнегативні бактерії становили 22,4\%. Серед них найбільшу частку мали E. coli (4,9\%), Klebsiella pneumoniae (4\%), Enterobacter spp. $(3,4 \%)$ та Klebsiella oxytoca (3,2\%). Ці результати мають певну схожість з опублікованими даними дослідників з інших країн.

Так, в систематичному огляді бактеріальних культур, отриманих ендоскопічно у пацієнтів із ХРС, відмічено, що до переліку видів переважно входять S. epidermidis $(24,8 \%)$ та S. aureus $(18,9 \%)$, за ними слідують Haemophilus influenzae (9,6\%), Pseudomonas aeruginosa (7,8\%), Streptococcus pneumoniae (7,0\%), Peptostreptococcus spp. (6,1\%) та Bacteroides (6,0\%) [10]. Крім того, за результатами досліджень, проведених у США, повідомляється, що найпоширенішими бактеріями, які виділені у пацієнтів із ХРС, були а-гемолітичний стрептокок $(21,9 \%)$, ентеробактерії (E. coli, Proteus mirabilis, Klebsiella pneumoniae) $(21,9 \%)$ та S. aureus $(15,6 \%)$ [14]. Результати бактеріального посіву зразків біопсії із слизової оболонки передніх решіткових клітин хворих на ХРС у Німеччині показали, що S. epidermidis $(81,4 \%)$, Corynebacterium spp. (41,9\%), а-гемолітичний стрептокок $(20,9 \%)$ та S. aureus $(18,6 \%)$ були основними аеробними мікроорганізмами [15]. Ще одне дослідження, проведене в період 2014-2016 рр. за участю китайських пацієнтів із ХРС, доводить, що найпоширенішими бактеріями, виділеними із зразків мазків СНХ, були S. epidermidis, Corynebacterium та S. aureus [5, 13].

У нашому дослідженні частота виявлення S. aureus $(39,7 \%)$ у хворих на ХРС була більшою порівняно з даними вищенаведених досліджень, що можна пояснити відмінностями контингенту пацієнтів, зокрема, у дослідження були включені дані про мікрокультури, виділені в умовах стаціонару, які взято інтраопераційно [5, 12-15], у нашому - лише амбулаторні. 3 іншого боку, ми також збирали зразки з СНХ, але в амбулаторних умовах. Інша причина розбіжностей може бути пов'язана з різними екологічними та медичними факторами. Про значимість місця забору зразків слизу свідчить дослідження з Південної Кореї, в якому відмічається, що рівень ізоляції S. aureus у верхньощелепному синусі дорослих пацієнтів становив 7,8\%, що відрізнялося від показника 19,1\% виділення від зразків CHX [16]. Такий рівень (<10\%) виявлення S. aureus у навколоносових синусах (інтраопераційно) підтверджений іншими дослідниками з Південної Кореї [7, 17].

У нашому дослідженні частота ізоляції бактерій у пацієнтів із ХРС без поліпів та з поліпами суттєво не відрізнялася. Цей результат узгоджується з дослідженнями, проведеними іншими авторами, які не повідомляли про суттєві відмінності у показниках ізоляції між пацієнтами з ХРС з поліпами та без $[13,15,18]$, проте у Південній Кореї встановлено відмінність за цим показником із суттєво вищим рівнем виявлення бактерій в осіб із ХРС без поліпозу [7], але дещо відрізняється від результатів попередніх досліджень. Проте у нашому дослідженні частота ізоляції бактерій у хворих на ХРС з поліпами (74,5\%) була помітно високою, як i в попередніх дослідженнях. Ми спостерігали, що частота ізоляції окремих бактерій у хворих на ХРС залежно від наявності поліпів відрізняється. Так, S. aureus та S. epidermidis частіше відмічали у хворих на ХРС з поліпами, тоді як Enterococcus faecalis та Streptococcus spp. - без поліпів у носі. Ці результати певною мірою узгоджуються з дослідженнями, проведеними у Китаї $[13,18]$.

Ми виявили високу поширеність S. epidermidis як у хворих на XPC з поліпами, так і без поліпів. Роль S. epidermidis у патогенезі ХРС залишається суперечливою, оскільки його часто можна виявити в СНХ здорових людей, а також хворих на ХРС [13, 18].

Побоювання щодо можливого збільшення атипових бактерій та стійких до АБ мікроорганізмів спонукало нас дослідити тенденції у видовому складі ізольованих бактерій та стійкості до АБ. Коли аналізували ці тенденції за останні 5 років (2015-2020рр.), S. aureus, S. epidermidis, Streptococcus spp. та Klebsiella pneumoniae продемонстрували тенденції до росту, які були значними, тоді як щодо Corynebacterium, E. coli та Enterobacter spp. відмічена суттєва тенденція до зменшення. Оскільки в інших дослідженнях Klebsiella spp. не була поширеною, іï збільшення може підвищити обізнаність про збільшення грамнегативних бактерій та їх роль у ХРС. Отже, слід розглядати антимікробну терапію, що ґрунту$\epsilon$ ться на результатах культури [5].

Для елімінації виявленої мікрофлори в осіб із гострою або загостренням хронічної інфекції рекомендується антибіотикотерапія [19]. Незважаючи на брак достовірних даних, що підтверджують їх ефективність, більшість лікарів застосовують АБ як компонент терапії [5]. Поява резистентних грамнегативних бактерій або MRSA внаслідок емпіричного та багаторазового застосування АБ може спричинити більш стійкий перебіг ХРС [11]. У нашому дослідженні частота виділення MRSA серед досліджуваних штамів становила $21 \%$, що свідчить про імовірно часте необґрунтоване застосування АБ для лікування ХРС. Отже, надмірне або неправильне застосування АБ широкого спектру дії може викликати резистентність штамів мікроорганізмів до цих препаратів. Тому з'ясування останніх тенденцій щодо складу та антибіотикорезистентності культур мікроорганізмів, виділених у пацієнтів із ХРС, $є$ важливим для контролю інфекцій і запобігання розвитку стійкості до АБ.

Таким чином, результати нашого дослідження та аналіз даних літератури підтверджують сучасні рекомендації щодо доцільності застосування АБ у випадках позитивних культуральних досліджень при інфекційних загостреннях у хворих на ХРС, в ідеалі - на культурах, що відбираються під ендоскопічним контролем. Слід дотримуватися обережності щодо застосування емпіричних АБ для лікування пацієнтів із ХРС.

\section{Висновки}

1. Частота виявлення S. aureus у осіб із XPC, яким планується дентальна імплантація, становить $39,7 \%$.

2. Найбільш ефективні щодо виділених штамів S. aureus, за даними антибіотикограми, - гентаміцин, ципрофлоксацин, офлоксацин, левофлоксацин, а також цефазолін та цефуроксим, що необхідно врахувати при лікуванні пацієнтів із носійством S. aureus або ХPC.

3. Частота виявлення MRSA становила $21 \%$.

4. Частота виявлення S. aureus у хворих на XРС з поліпами вища, ніж у пацієнтів без поліпів. 
Зв'язок роботи 3 науковими

\section{програмами, планами, темами}

Наукова робота проведена в рамках таких науково-дослідних робіт: «Удосконалення методів діагностики та лікування пацієнтів з окремими запальними та онкологічними захворюваннями вуха, носа та горла» (№ державної реєстрації РК 0117U006094) та «Оптимізація надання спеціалізованої та високоспеціалізованої медичної допомоги хірургічного профілю на принципах «хірургії швидкого шляху» при окремих захворюваннях щитоподібної та прищитоподібних залоз, носоглотки, внутрішніх і репродуктивних органів, черевної стінки, судин і суглобів, зокрема з використанням атомно-силової мікроскопії та із застосуванням методу преламінації для обробки імплантатів» (№ державної реєстрації 0119 U001046).

\section{Конфлікт інтересів}

Немає

\section{Фінансування}

Немає

\section{Список використаної літератури/References:}

1. Smith K.A., Orlandi R.R., RudmicL. (2015) CostofAdultChronicRhinosinusitis:ASystematic Review. The Laryngoscope, 125(7). DO1:10.1002/lary.25180.

2. MalanchukV.0., Grabovy 0.M., Zhukovtseva 0.I. (2015) Comparative analysis of biocompatibility of biomorphic ceramics based on silicon carbide and medical titanium: an experimental study. Bull. Probl. Biol. Med., 2(3): 166-169. (In Ukr.).

3. Rasouli R., Barhoum A., Uludag H. (2018) A review of nanostructured surfaces and materials for dental implants: surface coating, patterning and functionalization for improved performance. Biomater. Sci., 6(6): 1312-1338. doi: 10.1039/c8bm00021b. PMID: 29744496.

4. Camps-Font 0., Figueiredo R., Valmaseda-CastellónE., Gay-Escoda C. (2015) Postoperativelnfections After Dental Implant Placement: Prevalence, Clinical Features, and Treatment. Implant. Dent., 24(6): 713-719. doi: 10.1097/ID.0000000000000325. PMID: 26384096.

5. Cincik H., Ferguson B.J. (2006) The impact of endoscopic cultures on care in rhinosinusitis. Laryngoscope, 116(9): 1562-1568. doi: 10.1097/01.mlg.0000230402.66579.07.

6. Vickery T.W., Ramakrishnan V.R., Suh J.D. (2019) The Role of Staphylococcus aureus in Patients with Chronic Sinusitis and Nasal Polyposis. Curr. Allergy Asthma Rep., 19(4): 21. doi: 10.1007/s11882019-0853-7.

7. Kim D., Assiri A.M., Kim J.H. (2019) Recent Trends in Bacteriology of Adult Patients with Chronic Rhinosinusitis. J. Clin. Med., 8(11): 1889. doi: 10.3390/jcm8111889.

8. Minukhin VV, Kovalenko NI, Tkachenko VL etc. (2015) Normal nasopharyngeal microflora as a reservoir of multidrug-resistant strains of pathogens of upper respiratory tract infections. Annals of the Mechnikov Institute, 2: 195-199. (In Ukr.).

9. Korenyuk E.S. (2018) Disorders of the respiratory tract microbiota in children with respiratory diseases (literature review). Child health, 13(5): 506-515. (In Rus.).

10. Manes R.P., Batra P.S. (2012) Bacteriology and Antibiotic Resistance in Chronic Rhinosinusitis. Facial Plast. Surg. Clin. North Am., 20(1): 87-91. doi: 10.1016/j.fsc.2011.10.010.

11. Fokkens W.J., Lund V.J., Mullol J et al. (2012) European Position Paper on Rhinosinusitis and Nasal Polyps 2012. Rhinol. Suppl. 23: 1-298.

12. Thanasumpun T., Batra P.S. (2015) Endoscopically-derived bacterial cultures in chronic rhinosinusitis: Asystematic review. Am. J. Otolaryngol., 36: 686-691. doi: 10.1016/j.amjoto.2015.04.010.

13. WeiH.Z.,LYY.C.,Wang X.D. etal. (2018) The microbiology of chronic rhinosinusitis with and without nasal polyps. Eur. Arch. Otorhinolaryngol, 275: 1439-1447. doi: 10.1007/s00405-018-4931-6.

14. Brook I. (2006) Bacteriology of chronic sinusitis and acute exacerbation of chronic sinusitis. Arch. Otolaryngol. Head Neck Surg., 132: 1099-1101. doi: 10.1001/archotol.132.10.1099.

15. Niederfuhr A., Kirsche H., Riechelmann H., Wellinghausen N. (2009) The bacteriology of chronic rhinosinusitis with and without nasal polyps. Arch. Otolaryngol. Head Neck Surg., 135: 131-136. doi: 10.1001/archoto.2008.531.

16. Kim H.J., Lee K., Yoo J.B. et al. (2006) Bacteriological findings and antimicrobial susceptibility in chronic sinusitis with nasal polyp. Acta Otolaryngol., 126: 489-497.

\footnotetext{
Відомості про авторів: ка, Київ, Україна.

\section{Адреса для кореспонденції:}

Салманов Айдин Гурбанович

04112, Київ, вул. Дорогожицька, 9

E-mail:mozsago@gmail.com
}

Шкорботун Ярослав В. - кандидат медичних наук, доцент, завідувач відділення отоларингології Державної наукової установи «Науково-практичний центр профілактичної та клінічної медицини» Державного управління справами, Київ, Україна.

Салманов Айдин Гурбанович — доктор медичних наук, професор, завідувач науково-дослідної лабораторії Національного університету охорони здоров'я України імені П.Л. Шупи-
17. LeeC.W., LeeB.J.,Yoo S.H.,YiJ.S. (2014) Relationship between positive bacterial culture in maxillary sinus and surgical outcomes in chronic rhinosinusitis with nasal polyps. Auris. Nasus Larynx, 41: 446-449. doi: 10.1016/j.anl.2014.05.010.

18. Liu Q., Lu X., Bo M. et al. (2014) The microbiology of chronic rhinosinusitis with and without nasal polyps. Acta Otolaryngologica, 134(12): 1251-1258. doi: 10.3109/00016489.2013.879737.

19. Safier Frenkel T., Evans D.D. (2020) Are Antibiotics Useful in Acute Chronic Obstructive Pulmonary Disease Exacerbations? Implications for APRN Practice. Advanced Emerg. Nursing J., 42(3): 164-169. doi: 10.1097/TME.0000000000000313.

\section{Epidemiological assessment of nasal carriage of Staphylococcus aureus among patients for whom dental implantation is planned}

\section{Ya.V. Shkorbotun ${ }^{1,2}$, A.G. Salmanov'}

'Shupyk National Healthcare University of Ukraine, Kyiv, Ukraine

${ }^{2}$ State Institution of Science «Research and Practical

Center of Preventive and Clinical Medicine» State

Administration Department, Kyiv, Ukraine

Abstract. Objective: epidemiological assessment of Staphylococcus aureus (S. aureus) carriers in patients with chronic sinusitis who are scheduled for dental implantation. Object and methods of research. We examined 218 people aged 21 to 60 years ( 98 men, 120 women) who had various forms of chronic sinusitis (163 - with polyposis, 55 without polyposis) and who planned dental implantation. Isolation of cultures of microorganisms and their identification was carried out using routine methods based on current regulations. Sensitivity to antibiotics was determined by disco-diffusion method. Results. It was found that the middle nasal passage of patients with chronic rhinosinusitis, who planned dental implantation, were colonized by various microorganisms. The most commonly isolated bacteria were $S$. aureus (39.7\%). S. epidermidis (17\%) and Streptococcus spp. (10.3\%). No differences in the level of detection of bacteria on the criteria of atopy, asthma or current status of the smoker were found. Patients with chronic rhinosinusitis without nasal polyps showed a significantly higher rate of detection of various bacteria than patients with polyps. The frequency of isolation of individual bacteria between patients with chronic rhinosinusitis without polyps and with nasal polyps differed. S. aureus and S. epidermidis were more common in patients with chronic rhinosinusitis with polyps, while Enterococcus faecalis and Streptococcus spp. - in patients without nasal polyps. S. aureus strains were most sensitive to gentamicin, ciprofloxacin, ofloxacin, levofloxacin, cefazolin and cefuroxime, and the least sensitive to ampicillin, clarithromycin and erythromycin. Methicillin-resistant strains of S. aureus accounted for $21 \%$ of the total number of staphylococci isolated from patients. Conclusion. Chronic rhinosinusitis and carriers of S. aureus, in particular methicillin-resistant S. aureus in the nasal cavity - is a common problem often faced by patients who are shown dental implantation. When developing measures for the prevention and effective treatment of bacterial complications of dental implantation, it is necessary to take into account the data on microbial pathogens secreted in patients with chronic rhinosinusitis, and their possible resistance to antibiotics.

Key words: chronic rhinosinusitis, dental implantation, S. aureus, antibiotics, antimicrobial resistance.

\section{Information about the authors:}

Shkorbotun Yaroslav V. - MD, PhD, Assistant Professor, Head of Otolaryngology Department of State Institution of Science "Research and Practical Center of Preventive and Clinical Medicine» State Administration Department, Kyiv, Ukraine.

Salmanov Aidyn G. - MD, Dr. Sc., Full Professor, Head of the Scientific Research Laboratory of Shupyk National Healthcare University of Ukraine, Kyiv, Ukraine.

\section{Address for correspondence:}

Aidyn Salmanov

04112, Kyiv, Dorohozhytska St., 9

E-mail:mozsago@gmail.com 